\title{
KANDUNGAN UNSUR HARA PADA SERASAH DAUN SEGAR POHON (MAHONI, NANTU DAN MATOA)
}

\author{
NUTRIENT CONTENT IN FRESH LEAF LITTER OF TREES (MAHOGANY, NANTU, AND \\ MATOA)
}

\author{
Andre Edward Wowor 1 , Alfonsius Thomas'2, Johan A. Rombang ${ }^{2}$ \\ ${ }^{1}$ Mahasiswa Program Studi IImu Kehutanan, Fakultas Pertaian Unsrat Manado, 95115 \\ ${ }^{2}$ Staf Pengajar Jurusan Budidaya Pertanian, Fakultas Pertanian Unsrat Manado, 95115
}

\begin{abstract}
Plant life cycle requires adequate nutrient content in the planting media environment. Nutrients are naturally influenced by cyclical nutrition itself. Plants in the form of trees play a role in the synthesis of nutrients themselves. Trees play a role in absorbing nutrients in the soil and releasing nutrients through dead or harvested tissue, plant tissues that are most often canceled or killed because the weather is leaves. The nutritional needs of trees are different so the absorption, use and management of nutrients in trees is also different. The purpose of this study is to see the differences in species of Mahogany, Nantu and Matoa trees, which has the potential to contribute to the availability of nutrients. The method used in the study was a completely randomized design (CRD) with three replications. Analysis of nutrient $\mathrm{N}, \mathrm{P}$ and $\mathrm{K}$ was carried out in the laboratory using extraction of perhydrol by wet ingestion of $\mathrm{H}_{2} \mathrm{SO}_{4}+\mathrm{H}_{2} \mathrm{O}_{2}$. The results of the research obtained, that the fresh leaf litter of the nantu tree is the most potential as a nutrient-contributing tree to the surface soil.
\end{abstract}

Keywords : Nutrient, Nutrient cycle, Leaf Litter, Tree

\begin{abstract}
ABSTRAK
Siklus hidup tumbuhan membutuhkan ketercukupan kandungan unsur hara yang terdapat dalam lingkungan media tempat tumbuhnya. Unsur hara secara alami dipengaruhi oleh pensiklusan hara itu sendiri. Tumbuhan berupa pohon berperan dalam pensiklusan hara itu sendiri. Pohon berperan dalam penyerapan hara dalam tanah dan pelepasan hara melalui jaringan yang telah mati ataupun dipanen, jaringan tumbuhan yang paling sering digugurkan atau gugur akibat cuaca adalah daun. Kebutuhan hara pohon berbeda sehingga penyerapan, penggunaan, dan pengelolaan hara pada pohon juga berbeda. Tujuan penelitian ini adalah melihat perbedaan spesies pohon Mahoni, Nantu dan Matoa, yang berpotensi sebagai peyumbangan hara. Metode yang digunakan dalam penelitian adalah Rancangan Acak Lengkap $(\mathrm{RAL})$ dengan tiga ulangan. Analisis hara $\mathrm{N}, \mathrm{P}$ dan $\mathrm{K}$ dilakukan di laboratorium menggunakan ekstrasi perhidrol dengan pengabuan basah $\mathrm{H}_{2} \mathrm{SO}_{4}+\mathrm{H}_{2} \mathrm{O}_{2}$. Hasil penelitian yang diperoleh, bahwa serasah daun segar pohon nantu adalah yang paling berpotensi sebagai pohon penyumbang hara ke tanah permukaan. Kata kunci : Unsur Hara, Siklus Hara, Serasah daun, Pohon
\end{abstract}

Eugenia Volume 25 No. 1 Februari 2019 
Wowor, A.E., dkk. : Kandungan Unsur Hara Pada Serasah Daun

\section{PENDAHULUAN}

Siklus kehidupan tumbuhan tidak lepas dengan faktor lingkungan. Lingkungan yang merupakan tempat tumbuh terlebih pada tanah terkandung unsur-unsur hara yang dibutuhkan dalam pertumbuhan dan perkembangan tumbuhan. Hara esensial merupakan kebutuhan yang sangat mendesak dan jika tidak terpenuhi akan mengakibatkan terjadinya penyakit pada tanaman (Delvian, 2006). Unsur hara esensial tersebut penting karena memiliki fungsi dalam metabolisme yang tidak dapat digantikan oleh unsur lain, antara lain sebagai aktivator atau katalisator dalam proses sintesa protein, serta menjadi bahan penyusun sel atau jaringan tumbuhan (Syekhfani, 1998).

Unsur hara esensial dapat ditemukan pada tanah, udara maupun air hujan, yang jumlahmya dipengaruhi oleh siklus hara yang terjadi di alam. Tanah terbentuk dari pelapukan batuan-batuan yang mengandung unsur-unsur hara (Poerwowidodo, 1992). Unsur hara yang terdapat di udara seperti $S$ berasal dari erupsi dan aktifitas gunung berapi, partikel/garam yang terbawa angin atau ikut menguap bersama air ke udara dan $\mathrm{N}$ yang merupakan unsur terbesar yang terdapat di udara yang di fiksasi oleh beberapa spesies tumbuhan. Unsur pada air hujan adalah unsur yang ikut turun bersama air hujan, seperti unsur $\mathrm{N}$ yang tersedia karena energi dari kilat sehingga $\mathrm{N}_{2}$ dapat bereaksi dengan $\mathrm{O}_{2}$ yang menghasilkan nitrogen oksida dan larut dalam air hujan (Gardner, et al, 1991).

Kebutuhan unsur hara esensial terbagi dalam 2 sesuai jumlah kebutuhannya yaitu, unsur hara makro, unsur hara mikro (Agustina, 2004). Unsur makro terdiri dari: $\mathrm{C}, \mathrm{H}, \mathrm{O}, \mathrm{N}, \mathrm{P}, \mathrm{K}, \mathrm{Mg}, \mathrm{Ca}$, dan $S$, sedangkan unsur hara mikro yang dibutuhkan tanaman dalam jumlah kecil yaitu $\mathrm{Fe}, \mathrm{Mn}, \mathrm{Cu}, \mathrm{Zn}, \mathrm{B}$, $\mathrm{Mo}$, dan $\mathrm{Cl}$, serta unsur hara mikro tambahan yang bermanfaat bagi sebagian tanaman yaitu $\mathrm{Na}$, Co, $\mathrm{Va}, \mathrm{Ni}$, dan $\mathrm{Si}$. Kebutuhan hara esensial tidak boleh kurang dan harus tersedia, baik unsur hara makro maupun mikro. Kedua unsur hara sama-sama bermanfaat dalam siklus hidup tanaman, jika tidak tersedia maka tanaman tidak dapat melengkapi siklus hidupnya (Tisdale, et al, 1993).

Tumbuhan memperoleh hara dari lapisan tanah dan hara tersebut disimpan pada bagianbagian dari tumbuhan, selain hara yang diperoleh dari akar dalam tanah. Spesies legume mampu melakukan fiksasi $\mathrm{N}$ dari udara sehingga terjadi pertambahan jumlah $\mathrm{N}$ yang terakumulasi dalam tumbuhan (Sulieman dan Tran, 2015). Tumbuhan berupa pohon memiliki perakaran yang dapat menjangkau bagian-bagian tanah yang lebih dalam, dibandingkan dengan tumbuh-tumbuhan lain yang hanya memperoleh hara pada permukaan tanah. Perakaran pohon mampu masuk lebih dalam pada tanah dan menyerap seluruh hara yang tersedia pada bagian tanah yang larut oleh karena air tanah (Berry, 2006). Seluruh hara tersebut kemudian akan disalurkan pada bagian-bagian tumbuhan yang membutuhkan hara tersebut sesuai dengan kebutuhannya.

Peranan pohon dalam siklus hara adalah melalui penyerapan unsur hara dari dalam tanah dan pelepasan kembali unsur hara melalui jaringanjaringan yang telah mati atau dipanen. Jaringanjaringan pohon yang telah mati kemudian terdekomposisi dan menghasilkan senyawa-senyawa yang sederhana kembali kedalam tanah. Selain itu, sebagian jaringan tumbuhan yang telah mati dan jatuh ke permukaan tanah dapat menjadi sumber makanan bagi sebagian makhluk hidup. Unsurunsur hara dalam jaringan yang telah mati tersebut dikembalikan ke tanah melalui kotoran ataupun setelah mahluk hidup tersebut mati.

Bagian-bagian pohon yang paling sering digugurkan dan terdekomposisi adalah daun-daunan. Gugur daun memiliki transfer hara dari vegetasi ke lantai hutan yang lebih tinggi dibandingkan dengan gugur cabang dan pencucian karena air hujan (Golley, et. al., 1975). Pelepasan unsur-unsur hara akibat proses dekomposisi meningkatkan kesuburan tanah, tidak hanya meningkatkan kesuburan melalui penambahan hara tapi gugur daun yang terdapat dibawah pohon juga akan meningkatkan jumlah hewan tanah yang bermanfaat bagi aerasi tanah (Hartono, 2012). 
Kemampuan menyerap hara dan kebutuhan masing-masing tumbuhan berbeda, sehingga akumulasi dari hara pada tumbuhan berbeda Hasil penelitian Munis dan Swasono (2013) jumlah kandungan unsur hara yang terdapat pada daun tiga spesies pohon yang berbeda memiliki kandungan unsur hara yang berbeda pula. Hal yang sama juga dinyatakaan oleh Kang, et al, (1984).

Tujuan penelitian ini adalah untuk mengetahui kandungan unsur hara $\mathrm{N}, \mathrm{P}$ dan $\mathrm{K}$ dalam serasah daun segar spesies pohon; mahoni, nantu dan matoa. Manfaat dari penelitian ini adalah untuk mengetahui potensi tumbuhan sebagai penyumbang hara ke tanah permukaan dalam siklus unsur hara.

\section{METODE PENELITIAN}

Penelitian ini dilaksanakan di BKSDA SULUT Kecamatan Wanea Kelurahan Tingkulu Kota Manado dan Laboratorium BALAI PENELITIAN TANAMAN SAYURAN Lembang, Bandung Barat. Penelitian ini telah dilaksanakan selama 4 bulan pada bulan Juli sampai dengan bulan Oktober 2017.

Alat dan bahan yang digunakan ialah; Gunting, Oven, Komputer, Kamera, Alat tulis, Timbangan (gram), Tas Plastik, Amplop, Jaring, Label, Tali, dan Kertas Koran. Alat laboratorium spesifik; Alat destilator, Spektrophotometer, Flamephotometer dan Preaksi untuk metode pengabuan basah $\mathrm{H}_{2} \mathrm{SO}_{4}+\mathrm{H}_{2} \mathrm{O}_{2}$.

Penelitian ini menggunakan rancangan acak lengkap (RAL), dengan 3 perlakuan (3 Spesies berbeda yaitu mahoni (Swietenia macrophylla King.), nantu (Palaquium sp.), dan matoa (Pometia Pinnata Forst.). Setiap perlakuan diulang sebanyak 3 kali, untuk memperoleh sampel serasah daun segar. Analisis; Unsur N, Sampel serasah daun segar dihaluskan dan diekstrasi (perhidrol) dengan metode pengabuan basah $\mathrm{H} 2 \mathrm{SO} 4+\mathrm{H} 2 \mathrm{O} 2$ dan menggunakan alat destilator untuk memperoleh $\mathrm{N}$ total melalui metode Kjaldahl. Unsur P, Sampel serasah daun segar dihaluskan dan diekstrasi (perhidrol) dengan metode pengabuan basah $\mathrm{H} 2 \mathrm{SO} 4+\mathrm{H} 2 \mathrm{O} 2$ dan menggunakan alat dan metode Spektrophotometer. Unsur K, Sampel serasah daun segar dihaluskan dan diekstrasi (perhidrol) dengan metode pengabuan basah $\mathrm{H} 2 \mathrm{SO} 4+\mathrm{H} 2 \mathrm{O} 2$ dan menggunakan alat dan metode Flamephotometer.

Hasil analisis kandungan hara dari ketiga serasah daun segar diuji dengan menggunakan sidik ragam dan uji BNT pada tingkat kepercayaan 5\% untuk melihat perbedaan antar serasah daun segar pada ketiga spesies pohon.

Variabel yang diamati dalam penelitian ini adalah kandungan hara yang terdapat di serasah segar daun dari 3 spesies pohon [mahoni (Swietenia macrophylla King.), nantu (Palaquium sp.), dan matoa (Pometia Pinnata Forst.)]. Hara yang diamati adalah unsur $\mathrm{N}, \mathrm{P}$ dan $\mathrm{K}$.

\section{HASIL DAN PEMBAHASAN}

\section{Kandungan Hara N Serasah Daun Segar}

Hasil yang diperoleh dari pengujian laboratorium terhadap kandungan unsur hara $\mathrm{N}$ serasah daun segar mahoni, nantu dan matoa dapat dilihat pada tabel 1. Hasil analisis statistik dari kandungan unsur Nitrogen $(\mathrm{N})$ dari serasah daun segar mahoni, nantu dan matoa tidak berbeda nyata.

Hara N merupakan penyusun klorofil yang banyak terdapat pada daun. Klorofil memberikan warna hijau pada daun dan berperan dalam fotosintesis. Ketiga serasah daun segar pohon tersebut memiliki kandungan $\mathrm{N}$ yang relatif sama, dan tidak ada perbedaan terhadap jumlah $\mathrm{N}$ pada serasah daun segar. Serasah daun segar yang diperoleh pada umumnya sudah mulai menguning dan tidak tampak seperti daun segar umumnya yang belum digugurkan, gejala daun yang menguning merupakan salah satu gejala yang menunjukan adanya kekurangan terhadap hara $\mathrm{N}$ pada daun (Dwidjoseputro, 1992). Turunnya kadar hara N pada serasah daun segar dikarenakan $\mathrm{N}$ pada tanaman bersifat mobile sehingga dapat ditranslokasikan dari daun tua ke daun muda, terlebih untuk daun yang akan digugurkan. 
Tabel 1. Kadar N (\%) Serasah Daun Segar Pohon Mahoni, Nantu dan Matoa (Table 1. N Level (\%) of the leaves of the Mahogany Tree, Nantu and Matoa)

\begin{tabular}{cc}
\hline Jenis Pohon & Rata-Rata \\
\hline Mahoni & 0,82 \\
Nantu & 0,82 \\
Matoa & 0,81 \\
\hline
\end{tabular}

\section{Kandungan Hara P Serasah Daun Segar}

Hasil yang diperoleh dari pengujian laboratorium terhadap kandungan unsur hara $P$ serasah daun segar mahoni, nantu, dan matoa dapat dilihat pada tabel 2. Kadungan unsur hara Fosfor $(\mathrm{P})$ serasah daun segar nantu berbeda nyata dengan serasah daun segar mahoni dan matoa.

Hara $\mathrm{P}$ pada tanaman dibutuhkan dalam pembetukan senyawa ADP (adenosin difosfat), ATP (adenosin trifosfat), DPN (difosfopiridin), dan TPN (trifosfopiridin), yang fungsinya sebagai transport dan penyimpanan energi (Poerwowidodo, 1992). Hara $\mathrm{P}$ juga mempengaruhi akar dan batang pada tumbuhan, dimana dengan ketercukupan hara $P$ maka tumbuhan tersebut akan memiliki perakaran yang baik. Daun pohon nantu dan matoa memiliki tulang daun lebih tebal dibandingkan tulang daun dari pohon mahoni. Terkait jumlah hara $\mathrm{P}$ dari hasil rata-rata serasah daun segar nantu dan matoa yang berada pada nilai $0,1 \%$ dan $0,18 \%$, diduga karena hara $\mathrm{P}$ sering berada pada jaringan transport dan juga berperan pada bagian batang tanaman sehingga mempengaruhi jumlah hara $P$ yang terkandung pada serasah daun segar.

\section{Kandungan Hara K Serasah Daun Segar}

Hasil yang diperoleh dari pengujian laboratorium terhadap kandungan unsur hara $\mathrm{K}$ serasah daun segar mahoni, nantu, dan matoa dapat dilihat pada tabel 3 . Kadungan unsur hara Kalium (K) serasah daun segar nantu berbeda nyata dengan serasah daun segar mahoni dan matoa.

Hara $\mathrm{K}$ berfungsi dalam pengendalian air, sintesis protein, fotosintesis dan translokasi fotosintat. Wright, et. al. (2017) menyatakan bahwa daun pada daerah tropis berukuran lebih besar dibandingkan dengan daun yang berada lebih ke bagian kutub, karena iklim pada bagian tropis memiliki curah hujan dan kelembaban yang tinggi, jumlah panas dan radiasi matahari yang konstant dibanding iklim lainnya. Daun pada bagian tropis dapat menyeimbangkan tingkat panas yang diterima dengan ketersediaan air yang dimiliki untuk menjaganya tetap sejuk. Hara $\mathrm{K}$ merupakan hara yang berperan penting terhadap pengendalian air tersebut, proses penyejukan pada tanaman tropis akan bergantung pada hara $\mathrm{K}$ dalam mengatur kecepatan pelepasan air, agar pohon tidak kekurangan air dan tetap dingin pada musim kering. Pada pohon nantu yang memiliki daun paling besar dibandingkan pohon matoa dan mahoni, menyebabkan pohon tersebut beradaptasi dalam menjaga kesejukan daun tersebut dengan memasok hara $\mathrm{K}$ lebih besar pada daunnya sehingga daun tersebut tidak mudah untuk kehilangan air. Serasah daun segar dari pohon nantu yang jatuh pada umumnya berwarna hijau kekuning-kuningan dan lebih terlihat segar dibandingkan dengan kedua serasah daun segar pohon yang lain, sebaliknya serasah daun segar pohon matoa pada umumnya lebih kering dibandingkan dengan pohon mahoni. Hal ini diduga disebabkan kurangnya jumlah hara $\mathrm{K}$ yang terdapat pada daun tersebut. Hara $\mathrm{K}$ bertujuan untuk menjaga air dalam daun sehingga tidak mudah terjadi penguapan. Hal ini juga diperkuat dengan gejala yang tampak pada tumbuhan yang mengalami kekurang hara $\mathrm{K}$ yaitu daun akan lebih menguning (Dwidjoseputro, 1992).

\section{Perbandingan Hara Serasah Daun Segar}

Hasil uji menyatakan bahwa tidak terdapat perbedaan kandungan hara $\mathrm{N}$ ketiga serasah daun segar mahoni, nantu, dan mahoni. Ketiga serasah daun segar memiliki kandungan rata-rata hara $\mathrm{N}$ sebagai berikut; mahoni $(0,82 \% N)$, nantu $(0,82 \%$ $\mathrm{N})$, dan matoa $(0,81 \% \mathrm{~N})$, dengan besar nilai 
kandungan hara $\mathrm{N}$ pada ketiga serasah daun segar jika dibandingkan dengan kebutuhan minimum hara $\mathrm{N}$ tumbuhan yaitu $1 \% \mathrm{~N}$ (Tisdale, et. al., 1993), ketiga serasah daun segar belum dapat mencukupi kebutuhan tersebut. Jumlah hara $\mathrm{N}$ yang belum mencapai nilai kebutuhan per berat kering tumbuhan disebabkan karena sebelum daun digugurkan sebagian hara $\mathrm{N}$ ditranslokasikan ke bagian-bagian tumbuhan yang lain yang membutuhkannya (Millard and Grelet. 2010).

Kandungan hara $P$ serasah daun segar mahoni $(0,03 \% \mathrm{P})$ dan matoa $(0,1 \% \mathrm{P})$ tidak terdapat perbedaan, tapi memiliki perbedaan nyata dengan serasah daun segar nantu $(0,18 \% \mathrm{P})$. Jumlah kandungan hara $\mathrm{P}$ serasah daun segar dilihat dari nilai per berat kering, baik serasah daun segar nantu dan matoa sudah dapat mencukupi minimum kebutuhan hara $\mathrm{P}$ tumbuhan yaitu $0.1 \% \mathrm{P}$ (Tisdale, et. al, 1993), tapi tidak untuk serasah daun segar mahoni. Hara $P$ yang terdapat pada nantu dan matoa sudah cukup baik, meskipun hara $\mathrm{P}$ dikenal dengan sifat mobile-nya pada tumbuhan yang memungkinkan terjadinya translokasi, terlebih pada saat daun telah menua dan akan gugur (Cherbuy, et. al., 2001).

Kandungan hara $\mathrm{K}$ serasah daun segar nantu $(0,76 \% \mathrm{~K})$ memiliki perbedaan nyata terhadap serasah daun segar mahoni $(0,32 \% \mathrm{~K})$ dan matoa $(0,22 \% \mathrm{~K})$, baik mahoni dan matoa keduannya tidak memiliki perbedaan kandungan hara $\mathrm{K}$. Ketiga serasah daun segar secara nilai belum dapat mencukupi nilai minimum kebutuhan hara $\mathrm{K}$ tumbuhan yaitu $1 \% \mathrm{~K}$ (Tisdale, et al., 1993). Poerwidodo (1992) menyatakan hara K dalam tumbuhan berbentuk ion $\mathrm{K}^{+}$dan tidak membentuk senyawa dengan hara lain, sehingga unsur hara $\mathrm{K}$ bersifat sangat mobile tidak dan terikat dalam bahan organik tumbuhan, sehingga perpindahan unsur $\mathrm{K}$ sering terjadi.

Tabel 2. Kadar P (\%) Serasah Daun Segar Pohon Mahoni, Nantu dan Matoa

(Table 2. P (\%) The Fresh of The Mahogany, Nantu and Matoa)

\begin{tabular}{cc}
\hline Jenis Pohon & Rata-Rata \\
\hline Mahoni & $0,03^{\mathrm{a}}$ \\
\hline Nantu & $0,18^{\mathrm{b}}$ \\
\hline Matoa & $0,10^{\mathrm{a}}$ \\
\hline BNT 5\% & 0,073
\end{tabular}

Notasi yang sama tidak menunjukan perbedaan

Tabel 3. Kadar K (\%) Serasah Daun Segar Pohon Mahoni, Nantu dan Matoa (Table 3. K (\%) The Fresh of The Mahogany, Nantu and Matoa)

\begin{tabular}{cc}
\hline Jenis Pohon & Rata-Rata \\
\hline Mahoni & $0,32^{\mathrm{a}}$ \\
\hline Nantu & $0,76^{\mathrm{b}}$ \\
\hline Matoa & $0,22^{\mathrm{a}}$ \\
\hline BNT 5\% & 0,152
\end{tabular}

Notasi yang sama tidak menunjukan perbedaan 


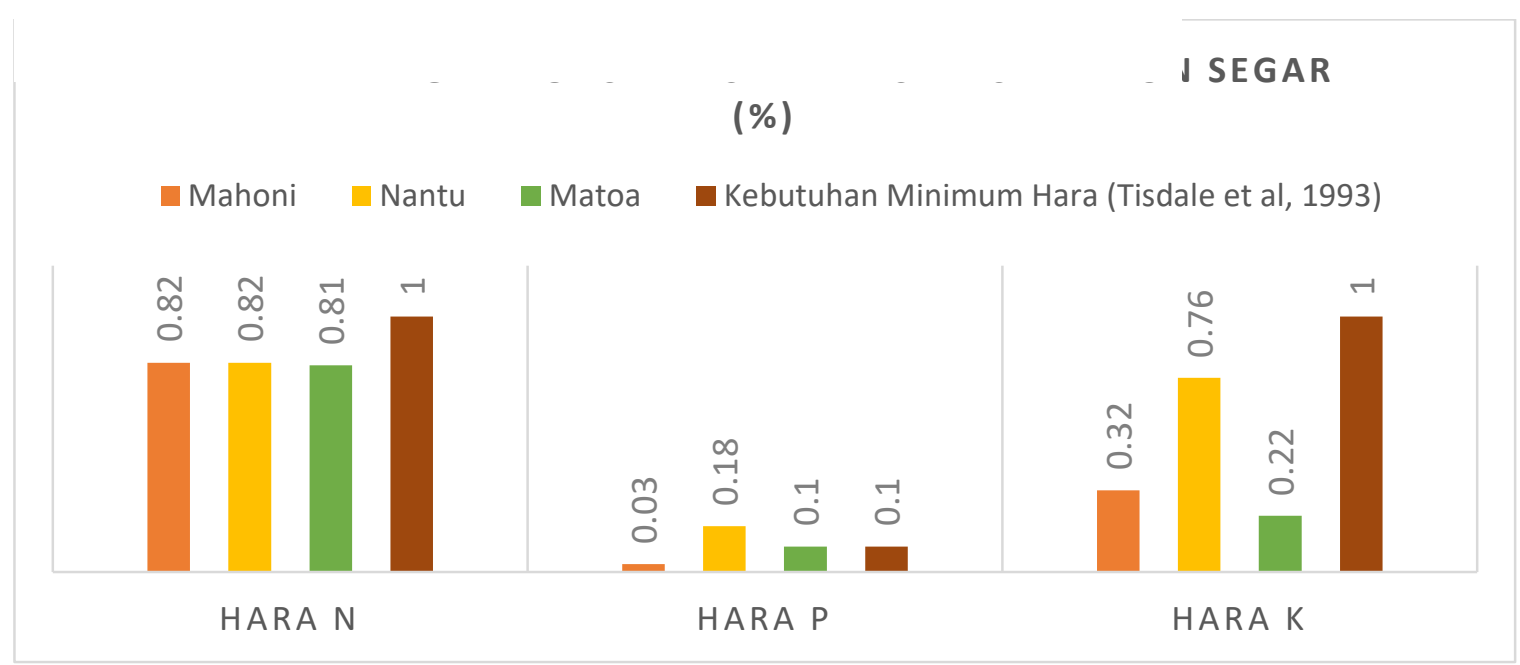

Grafik 1. Perbandingan Konsentrasi Hara Serasah Daun Segar (\%)

(Chart 1. Hara Concentration Ratio Fresh Leaf Shew (\%)

Berdasarkan pada hasil uji yang diperoleh disimpulkan bahwa serasah daun segar nantu merupakan serasah daun segar yang paling berpotensi sebagai penyumbang hara tanah permukaan. Serasah daun segar nantu merupakan serasah daun segar yang memberikan nilai sumbangan hara terbesar dibanding serasah daun segar matoa dan mahoni, dengan sumbangan hara $\mathrm{N}(0,82 \%), \mathrm{P}(0,18 \%)$, dan $\mathrm{K}(0,76 \%)$.

\section{KESIMPULAN DAN SARAN}

\section{Kesimpulan}

Berdasarkan Hasil Penelitian diperoleh kesimpulan yaitu: 1) Kandungan unsur hara pada serasah daun segar pohon: a) Mahoni; 0,82\% $\mathrm{N}$, 0,03\% P, dan 0,32\% K; b) Nantu; 0,82\% N, 0,18\% $\mathrm{P}$, dan $0,76 \% \mathrm{~K}$; c) Matoa; 0,81\% N, 0,1\% P, dan $0,22 \%$ K. 2) Tidak ada perbedaan kandungan hara serasah daun segar antara mahoni dan matoa. 3) Kandungan hara $\mathrm{P}$ dan $\mathrm{K}$ serasah daun segar nantu berbeda nyata dengan serasah daun segar mahoni dan matoa. 4) Serasah daun segar nantu adalah yang paling berpotensi sebagai penyumbang hara ke tanah permukaan.

\section{Saran}

Hasil dari penelitian ini perlu diperdalam lagi dengan jumlah produksi serasah daun segar pohon per tahun, agar dapat diaplikasikan terhadap suatu sistem sebagai sumber hara permukaan tanah yang konsisten.

\section{DAFTAR PUSTAKA}

Agustina, L.. 2004. Dasar Nutrisi Tanaman. Rineka Cipta. Jakarta.

Berry, W. and A. Howard. 2006. The Soil and Health, A Study of Organic Agriculture. The University Press of Kentucky. Kentucky.

Cherbuy, B., R. Joffre, D. Gillon and S. Rambal. 2001. Internal remobilization of carbohydrates, lipids, nitrogen and phosphorus in the Mediterranean evergreen oak Quercus ilex. Tree Physiology 21. Heron Publishing. Canada. p.9-17.

Delvian. 2006. Siklus Hara: Faktor Penting Bagi Pertumbuhan Pohon dalam Pengembagan Tanaman Industri. Karya Tulis. Universitas Sumatera Utara. Medan. 
Dwidjoseputro, D.. 1992. Pengantar Fisiologi Tumbuhan. PT Gramedia Pustaka Umum. Jakarta.

Gardner, F.P., R.B. Pearce, dan R.L. Mitchell. 1991. Fisiologi Tanaman Budidaya. UI-Press, Jakarta.

Golley, F.B., J.T. McGinnis, R.G. Clements, G.I. Child and M.J. Duever. 1975. Mineral Cycling in a Tropical Moist Forest Ecosystem. The University of Georgia Press. Athens.

Hartono, Bambang T., 2012. Mulsa Daun Kering: Pengendali Gulma dan Penyubur Tanah di Hutan Tanaman: Murah, mudah dan ramah lingkungan. Kementerian Kehutanan, Badan Penelitian Dan Pengembangan Kehutanan, Pusat Penelitian Dan Pengembangan Peningkatan Produktivitas Hutan. Bogor.

Kang, B.T., G.F. Wilson, and T.L. Lawson. 1984. Alley Cropping a Stable Alternative to Shifting Cultivation. International Institute of Tropical Agriculture (IITA). Ibadan, Nigeria.

Millard, P. and G.A. Grelet. 2010. Nitrogen storage and remobilization by trees: ecophysiological relevance in a changing world. Tree Physiology 30. Oxford University Press. P.1083-1095.
Munir, M. dan M. A. H. Swasono, 2013. Potensi Pupuk Hijau Organik (Daun Trembesi, Daun Paitan, Daun Lamtoro) sebagai Unsur Kestabilan Kesuburan Tanah. Jurnal Agromix vol 2 No 2 September 2013.

Poerwowidodo, M.. 1992. Telaah Kesuburan Tanah. Angkasa, Bandung.

Sulieman, S. and L.S.P. Tran. 2015. Legume Nitrogen Fixation in a Changing Environment. Springer, Switzerland.

Syekhfani. 1998. Hara - Air - Tanah - Tanaman. Universitas Brawijaya. Malang.

Tisdale, S.L., W.L. Nelson, J.D. Beaton, and J.L. Havlin. 1993. Soil fertility and fertilizers. $5^{\text {th }}$ ed. Macmillan Pub. Comp. New York.

Wright, I. J., N. Dong, V. Maire, I. C. Prentice, M. Westoby, S. Díaz, R. V. Gallagher, B. F. Jacobs, R. Kooyman, E. A. Law, M. R. Leishman, Ü. Niinemets, P. B. Reich, L. Sack, R. Villar, H. Wang, and P. Wilf. 2017. Global climatic drivers of leaf size. Science 01 Sep 2017 Vol. 357, Issue 6354. American Association for the Advancement of Science. pp. 917-921. 